\title{
Haematological alterations due to lung diseases in sheep and goats of Jammu region
}

\author{
Nishchal Dutta, Shafiqur Rahman, Shagufta Azmi and Muneer Ahmad Dar ${ }^{{ }^{*}}$ \\ Divison of Veterinary Pathology, Faculty of Veterinary and Animal Sciences and Animal Husbandry (FVSc \& \\ AH), SKUAST Jammu-181102 (J\&K), INDIA \\ ${ }^{1}$ Department of Veterinary Pharmacology and Toxicology, Khalsa College of Veterinary and Animal Sciences, \\ Amritsar-143001 (Punjab), INDIA \\ *Corresponding Author: E-mail: drmuneer30@gmail.com
}

Received: September 12, 2016; Revised received: April 7, 2017; Accepted: August 12, 2017

\begin{abstract}
The present study was conducted for evaluation of haematological parameters in sheep (330) and goat (230) having various lung affections that were slaughtered routinely as a source of food in Jammu region (Gujjar Nagar, Dogra Hall, Bishnah and Nagrota). About 25.75\% (85) and 21.30\% (49)of lungs examined in sheep and goats respectively were found to have parasitic infestation of Hydatidosis, Myiasis and Mulleriuscapillaris. Furthermore about $31.81 \%$ (105) and $29.13 \%$ (67) of selected lungs had pathological conditions of pneumonia, abscess and haemorrhage in sheep and goats respectively. Diseased sheep and goats reflected significant decrease in haemoglobin $(\mathrm{Hb})$, packed cell volume (PCV) and erythrocytes (RBC) in parasitic infestation of Myiasis as compared to control while non significant alteration in these parameters was observed in conditions of Hydatidosis, M. capillaris, pneumonia, abscess and haemorrhage. Mean corpuscular volume (MCV) decreased significantly in Myiasis of sheep and haemorrhagic lungs of goats while no significant change was observed in mean corpuscular haemoglobin $(\mathrm{MCH})$ and mean corpuscular haemoglobin concentration $(\mathrm{MCHC})$ values. Significant increase in leucocytes (WBC), neutrophils, monocytes, eosinophils were observed in both sheep and goats affected with various parasitic and pathological lung disesases with no significant change in basophilic count. Lymphocytic count decreased in all these adversed lung conditions as compared to healthy ones. Parasitic infection though not mixed one especially that of Myiasis comparatively has significant affected on blood parameters. The present study signifies the complementary importance of ante -mortem examination with that of post-mortem inspection in various parasitic and pathological affections of lungs.
\end{abstract}

Keywords: Diseases, Goat, Haematology, Lung, Sheep

\section{INTRODUCTION}

Lungs arean important organs of the body. Enclosed in double pleural membrane, they are twin conical structures located on either side of the heart (Drake et al., 2014).Each lung is a mass of branching airways which get narrower and narrower as they approach the alveoli (Young et al., 2006). The walls of these airways produce mucus to keep the internal environment of the lungs moist; they are also lined with tiny hairs which beat together trapping dust and other foreign particles and move them out of the lungs so that they can be expelled by coughing or sneezing (Pawlina, 2015). Foreign particles which remain in the lungs, and of course any opportunistic viruses, bacteria, parasites, fungi etc cause local inflammation and excessive production of mucus (Brian et al., 2014). If many small airways become blocked and many clusters of alveoli become flooded with mucus, respiration deteriorates. In bronchitisand pneumonia the lungs are partially suffocated by their own secretions (Lockie, 1998).
Also, various bacterial pathogens are associated with the lung diseases. Some of the common bacterial pathogens associated are Staphylococcus, Streptococcus, Pasteurella and Pseudomonas. Though Staphyloccocus and Streptococcus are normal inhabitants but they cause secondary infections (Bhandareet al., 2010) Various affections of lungs included congenital anomalies, calcinosis, haemorrhage, pulmonary oedema, pulmonary embolism, pulmonary infarction, atelectasis, emphysema, pneumonia etc. Different types of pneumonias encountered in sheep and goats include bronchopneumonia, interstitial pneumonia, embolic pneumonia and granulomatous pneumonia. Parasitc affections of lungs include verminous pneumonia, hydatid cysts and Oestrusovis infection in sheep and goats (Vegad and Swamy, 2010). Sheep and goats are useful as they supply quality protein and revenue to man, but on the other hand they serve as vehicles of disease transmission. Besides economic losses, diseases of sheep and goats might constitute an epidemiologic and zoonotic threat. As such problems con- 
cerning meat hygiene and possible health risks to the consumer should be documented during both ante-mortem and post-mortem examination. In this context, meat inspection data are a potential source of information and have an important role to play in epidemiology and preventive veterinary medicine (Gracey et al., 2009). However, this source of information is not being fully exploited worldwide. Present study was, therefore, undertaken to study the prevalence of parasitic and pathological conditions of lungsand retrospective correlation was made with various hematological parameters in sheep and goats of Jammu region.

\section{MATERIALS AND METHODS}

Animals and design: The study was conducted on 560 animals which included sheep (330) and goats (230) that were slaughtered routinely as a source of food from neighbouring areas of the Jammu division. The selected areas having govt. recognized abattoirs included Dogra Hall and Gujjar Nagar along with unorganized abattoirs of Nagrota and Bishnah.

Sample collection and analysis: Prior to post mortem confirmation of lungs, evaluation of various haematological parameters of sheep and goat in in all the selectedabattoirs were conducted. For that purpose about $5 \mathrm{ml}$ of blood sample were collected at the time of ante-mortem examination in the sterile vials containing EDTA at the rate of $2 \mathrm{mg} / \mathrm{ml}$ of blood as anticoagulant and processed for the estimation of Haemoglobin concentration $(\mathrm{Hb})$, Packed cell volume (PCV), Total erythrocyte count (TEC), Total leukocyte count (TLC) and differential leukocyte count (DLC) as per standard methods described by Schalm et al. (1975). This was followed by post-mortem examination of lung samples of sheep and goats collected from these two areas for the various parasitic (Hydatidosis, Myiasis and Mullerius capillaries) and pathological conditions (Pnuemonia, abscess and haemorrhages). Lung samples of sheep and goats collected were examined for the presence of pneumonia, hydatidosis, bronchitis, tuberculosis, emphysema, pulmonaryfibrosis and other pathological conditions. Number of cysts, size and volume of cyst, viability of cyst were also recorded. The carcasses included in this study were inspected carefully by visual examination. The presence of cysts in lung organ was examined by naked eye and careful palpation. Cysts of infected organs were counted and their size was measured by special callipers measuring scale. Infected organs were transported to the laboratory at Division of Veterinary Pathology, R.S. Pura (SKUAST-Jammu) over ice.

Statistical analysis : The data generated was subjected to one way ANOVA employing Duncan descriptive statistical analysis as per method described by Snedecor and Cochran (1994).

\section{RESULTS}

The animals after post mortem examination revealed both parasitic and pathological conditions of lungs. About $25.75 \%$ of lungs examined were found to have parasitic infestation of Hydatidosis, Myiasis and Mulleriuscapillarisand about $31.81 \%$ of selected lungs had pathological conditions of pneumonia, abscess and haemorrhage in sheep. The parasitic and pathological conditions of same nature in goats were $21.30 \%$ and $29.13 \%$ respectively. Over all prevalence of pathological condition(Pneumonia, abscess and haemorrhages) $(30.71 \%)$ were found to be higher than parasitic (Hydatidosis, Myiasis and M.capillaries)(23.92\%) in sheep and goats (table 1).

The data on average haematological values in sheep with lung diseases has been summerised in Table 2 . Diseased sheep reflected significant $(\mathrm{P}<0.05)$ decrease in haemoglobin, $\mathrm{PCV}, \mathrm{RBC}$ and $\mathrm{MCV}$ in parasitic infestation of Myiasis ascompared to control while non significant alteration in these parameters was observed in conditions of Hydatidosis, M. capillaris, pneumonia, abscess and haemorrhage. No significant change was observed in $\mathrm{MCH}$ and $\mathrm{MCHC}$ haematological indices in diseased sheep as compared to normal one. WBC count increased significantly in sheep affected with Hydatidosis, Myiasis, pneumonia, abscess and haemorrhage. The values of neutrophils, monocyte and eosinophil increased significantly in all adverse parasitic and pathological conditions while significant decrease in lymphocytes was observed in all these

Table 1. Species wise prevalence (\%) of lung diseases in sheep and goats $(\mathrm{N}=560)$.

\begin{tabular}{lcccccc}
\hline Diseases & \multicolumn{2}{c}{ Sheep (N=330) } & \multicolumn{2}{c}{ Goats (N=230) } & \multicolumn{2}{c}{ Total (N=560) } \\
\cline { 2 - 7 } & $\mathbf{n}$ & Prevalence(\%) & N & Prevalence(\%) & n & Prevalence (\%) \\
\hline $\begin{array}{l}\text { Parasitic infestation } \\
\text { (Hydatidosis, Myiasis, M. }\end{array}$ & 85 & 25.75 & 49 & 21.30 & 134 & 23.92 \\
$\begin{array}{l}\text { Capillaries) } \\
\begin{array}{l}\text { Pathological conditions } \\
\text { (Pneumonia, abscess, } \\
\text { haemorrhages) }\end{array}\end{array}$ & 105 & 31.81 & 67 & 29.13 & 172 & 30.71 \\
\hline
\end{tabular}

$\mathrm{N}=$ Total number of lung samples examined, $\mathrm{n}=$ total number of infected lung samples, $\mathrm{P}$ (Prevalence $\%$ ) $=\mathrm{n} / \mathrm{N} * 10$ 
Table 2. Haematological parameters (Mean $\pm \mathrm{SE}$ ) in lung diseases of sheep. Means within row with different superscripts differ significantly $(\mathrm{P}<0.05)$.

\begin{tabular}{|c|c|c|c|c|c|c|c|}
\hline Parameters & $\begin{array}{l}\text { Control } \\
\text { (Healthy) }\end{array}$ & Hydatidosis & Myiasis & M.capillaris & Pneumonia & Abscess & $\begin{array}{l}\text { Haemor- } \\
\text { rhage }\end{array}$ \\
\hline $\mathrm{Hb}(\mathrm{g} \%)$ & $11.20 \pm 0.35^{\mathrm{a}}$ & $10.20 \pm 0.24^{\mathrm{a}}$ & $8.00 \pm 0.35^{b}$ & $10.40 \pm 0.21^{\mathrm{a}}$ & $11.18 \pm 0.24^{\mathrm{a}}$ & $10.35 \pm 0.24^{\mathrm{a}}$ & $10.20 \pm 0.14^{\mathrm{a}}$ \\
\hline PCV (\%) & $35.30 \pm 1.00^{\mathrm{a}}$ & $33.00 \pm 0.42^{\mathrm{a}}$ & $24.30 \pm 3.00^{\mathrm{b}}$ & $31.00 \pm 0.22^{\mathrm{a}}$ & $34.00 \pm 0.42^{\mathrm{a}}$ & $33.00 \pm 0.62^{\mathrm{a}}$ & $33.00 \pm 0.12^{\mathrm{a}}$ \\
\hline $\operatorname{RBC}\left(10^{6 / \text { cu.mm }}\right)$ & $11.20 \pm 0.68^{\mathrm{a}}$ & $11.00 \pm 1.20^{\mathrm{a}}$ & $8.56 \pm 1.00^{\mathrm{b}}$ & $10.00 \pm 1.00^{\mathrm{a}}$ & $11.00 \pm 1.40^{\mathrm{a}}$ & $11.19 \pm 0.40^{\mathrm{a}}$ & $10.00 \pm 1.20^{\mathrm{a}}$ \\
\hline $\operatorname{MCV}(\mathrm{fl})$ & $31.51 \pm 0.40^{\mathrm{a}}$ & $30.00 \pm 0.21^{\mathrm{a}}$ & $28.38 \pm 0.78^{b}$ & $29.00 \pm 0.11^{\mathrm{a}}$ & $31.00 \pm 0.21^{\mathrm{a}}$ & $31.00 \pm 0.21^{\mathrm{a}}$ & $30.00 \pm 0.81^{\mathrm{a}}$ \\
\hline $\mathrm{MCH}(\mathrm{pg})$ & $10.24 \pm 0.32^{\mathrm{a}}$ & $9.27 \pm 0.52^{\mathrm{a}}$ & $9.34 \pm 0.57^{\mathrm{a}}$ & $8.17 \pm 0.32^{\mathrm{a}}$ & $10.22 \pm 0.52^{\mathrm{a}}$ & $10.20 \pm 0.72^{\mathrm{a}}$ & $09.37 \pm 0.52^{\mathrm{a}}$ \\
\hline MCHC (g/dl) & $31.72 \pm 0.42^{\mathrm{a}}$ & $30.90 \pm 0.90^{\mathrm{a}}$ & $30.92 \pm 0.18^{\mathrm{a}}$ & $29.10 \pm 0.70^{\mathrm{a}}$ & $31.60 \pm 1.90^{\mathrm{a}}$ & $30.68 \pm 0.90^{\mathrm{a}}$ & $30.95 \pm 0.90^{\mathrm{a}}$ \\
\hline $\mathrm{WBC}\left(10^{3 / \mathrm{cu} . \mathrm{mm}}\right)$ & $8.50 \pm 0.30^{\mathrm{a}}$ & $11.20 \pm 0.16^{\mathrm{b}}$ & $13.20 \pm 1.10^{\mathrm{c}}$ & $10.20 \pm 0.06^{\mathrm{a}}$ & $12.30 \pm 1.30^{\mathrm{b}}$ & $13.44 \pm 1.10^{\mathrm{c}}$ & $12.20 \pm 1.10^{\mathrm{b}}$ \\
\hline Neutrophil (\%) & $32.10 \pm 0.21^{\mathrm{a}}$ & $42.01 \pm 0.50^{\mathrm{b}}$ & $50.00 \pm 1.60^{c}$ & $40.01 \pm 0.70^{\mathrm{b}}$ & $51.00 \pm 1.20^{\mathrm{c}}$ & $53.00 \pm 1.60^{\mathrm{c}}$ & $51.00 \pm 1.20^{\mathrm{c}}$ \\
\hline Lymphocyte (\%) & $60.30 \pm 0.46^{\mathrm{a}}$ & $40.60 \pm 0.22^{\mathrm{b}}$ & $41.00 \pm 2.08^{b}$ & $39.30 \pm 0.12^{\mathrm{b}}$ & $42.00 \pm 1.08^{\mathrm{b}}$ & $42.00 \pm 1.08^{b}$ & $41.32 \pm 2.18^{\mathrm{b}}$ \\
\hline Monocyte (\%) & $2.00 \pm 0.26^{\mathrm{a}}$ & $4.00 \pm 0.62^{\mathrm{b}}$ & $5.10 \pm 0.20^{\mathrm{b}}$ & $3.90 \pm 0.72^{\mathrm{b}}$ & $5.32 \pm 0.10^{\mathrm{b}}$ & $5.40 \pm 0.20^{\mathrm{b}}$ & $5.20 \pm 0.30^{\mathrm{b}}$ \\
\hline Eosinophil (\%) & $5.00 \pm 0.60^{\mathrm{a}}$ & $9.50 \pm 0.62^{\mathrm{b}}$ & $8.00 \pm 4.30^{\mathrm{b}}$ & $9.10 \pm 0.42^{\mathrm{b}}$ & $8.30 \pm 2.30^{\mathrm{b}}$ & $9.00 \pm 2.30^{\mathrm{b}}$ & $8.12 \pm 3.30^{\mathrm{b}}$ \\
\hline Basophil (\%) & $0 \pm 0.24^{\mathrm{a}}$ & $1 \pm 0.13^{\mathrm{a}}$ & $0 \pm 0.25^{\mathrm{a}}$ & $1 \pm 0.13^{\mathrm{a}}$ & $0 \pm 0.25^{\mathrm{a}}$ & $0 \pm 0.22^{\mathrm{a}}$ & $0 \pm 0.23^{\mathrm{a}}$ \\
\hline
\end{tabular}

parasitic and pathological conditions of lung as compared to healthy one. No significant change in basophils was observed in any of these parasitic and pathological conditions of lungs in sheep.

In goats, lungs infested with Myiasis showed significant decrease of $\mathrm{Hb}$ and PCV while no significant change was observed in other disease conditions as compared to control (Table 3). TEC decreased in conditions of Myiasis and Haemorrhage with no change in other parasitic and pathological conditions. MCV value changed only in haemorrhagic conditions of lungs of goats. Values of $\mathrm{MCH}$ and $\mathrm{MCHC}$ revealed non-significant changes in all the adverse parasitic and pathological conditions of lungs of goats. WBC and neutrophils significantly increased in all the diseased conditions of lung with more significant increase wasobserved in the pathological condition of abscess. Concentration of lymphocytes decreased significantly in all the conditions with more significant decrease observed in parasitic condition of Myiasis. As compared to healthy lungs, monocytes and eosinophils increased significantly in all adverse parasitic and pathological conditions of lungs in goats.

\section{DISCUSSION}

Significant decrease in $\mathrm{Hb}, \mathrm{PCV}$, TEC in sheep and goats infected with Myiasisand a non-significant decrease in theses parameters in hydatidosis, Mulleriuscapillaris, pneumonia, abscess and haemorrhage was observed.These results are supported by the study conducted by Lipeckaet al. (2010) in lambs and ewe who observed significant decrease in various blood parameters in parasitic as compared to pathological affections.Similarly, Khan and Khan (1996) observed non-significant difference in haematological parameters in lungs (pneumonic) conditions of small ruminants. Non significant decrease in these parameters were also reported by

Table 3. Haematological parameters (Mean \pm SE) in lung diseases of goats. Means within row with different superscripts differ significantly $(\mathrm{P}<0.05)$.

\begin{tabular}{|c|c|c|c|c|c|c|c|}
\hline Parameters & Control & Hydatidosis & Myiasis & M.capillaris & Pneumonia & Abscess & $\begin{array}{c}\text { Haemor- } \\
\text { rhage }\end{array}$ \\
\hline $\mathrm{Hb}(\mathrm{g} \%)$ & $10.50 \pm 0.25^{\mathrm{a}}$ & $9.50 \pm 0.14^{\mathrm{a}}$ & $8.35 \pm 0.65^{b}$ & $9.20 \pm 0.24^{\mathrm{a}}$ & $10.20 \pm 0.24^{\mathrm{a}}$ & $10.35 \pm 0.24^{\mathrm{a}}$ & $9.20 \pm 0.14^{\mathrm{a}}$ \\
\hline PCV (\%) & $31 \pm 1.00^{\mathrm{a}}$ & $30.00 \pm 0.20^{\mathrm{a}}$ & $25.00 \pm 2.00^{\mathrm{b}}$ & $30.00 \pm 0.42^{\mathrm{a}}$ & $30.00 \pm 0.42^{\mathrm{a}}$ & $30.00 \pm 0.62^{\mathrm{a}}$ & $28.00 \pm 0.12^{\mathrm{a}}$ \\
\hline $\operatorname{RBC}\left(10^{6 / \text { cu.mm }}\right.$ & $13.00 \pm 0.48^{\mathrm{a}}$ & $12.86 \pm 0.10^{\mathrm{a}}$ & $10.67 \pm 1.00^{\mathrm{b}}$ & $12.00 \pm 1.20^{\mathrm{a}}$ & $11.00 \pm 1.40^{\mathrm{a}}$ & $11.56 \pm 0.40^{\mathrm{a}}$ & $10.00 \pm 1.20^{\mathrm{b}}$ \\
\hline $\operatorname{MCV}(\mathrm{fl})$ & $23.84 \pm 0.12^{\mathrm{a}}$ & $23.32 \pm 0.13^{\mathrm{a}}$ & $22.43 \pm 0.10^{\mathrm{a}}$ & $22.00 \pm 0.21^{\mathrm{a}}$ & $22.00 \pm 0.21^{\mathrm{a}}$ & $21.00 \pm 0.21^{\mathrm{a}}$ & $20.00 \pm 0.81^{\mathrm{b}}$ \\
\hline $\mathrm{MCH}(\mathrm{pg})$ & $8.07 \pm 0.12^{\mathrm{a}}$ & $7.38 \pm 0.02^{\mathrm{a}}$ & $7.82 \pm 0.52^{a}$ & $7.27 \pm 0.52^{\mathrm{a}}$ & $7.27 \pm 0.52^{\mathrm{a}}$ & $7.29 \pm 0.72^{\mathrm{a}}$ & $07.37 \pm 0.52^{\mathrm{a}}$ \\
\hline $\mathrm{MCHC}(\mathrm{g} / \mathrm{dl})$ & $33.87 \pm 1.00^{\mathrm{a}}$ & $33.33 \pm 0.41^{\mathrm{a}}$ & $32.40 \pm 0.01^{\mathrm{a}}$ & $32.90 \pm 0.90^{\mathrm{a}}$ & $31.90 \pm 1.90^{\mathrm{a}}$ & $30.68 \pm 0.90^{\mathrm{a}}$ & $30.95 \pm 0.90^{\mathrm{a}}$ \\
\hline $\mathrm{WBC}\left(10^{3} /\right.$ cu.mm $)$ & $9.56 \pm 0.47^{\mathrm{a}}$ & $11.50 \pm 0.37^{\mathrm{b}}$ & $10.00 \pm 1.65^{\mathrm{b}}$ & $11.20 \pm 0.16^{\mathrm{b}}$ & $12.23 \pm 1.30^{\mathrm{b}}$ & $13.04 \pm 1.10^{\mathrm{c}}$ & $10.20 \pm 1.10^{\mathrm{b}}$ \\
\hline Neutrophil (\%) & $39.00 \pm 0.24^{\mathrm{a}}$ & $44.10 \pm 0.90^{\mathrm{b}}$ & $51.00 \pm 1.31^{\mathrm{c}}$ & $43.01 \pm 1.50^{\mathrm{b}}$ & $50.00 \pm 1.20^{\mathrm{c}}$ & $54.00 \pm 1.60^{\mathrm{c}}$ & $45.00 \pm 1.20^{\mathrm{c}}$ \\
\hline Lymphocyte (\%) & $47.00 \pm 0.29^{\mathrm{a}}$ & $41.30 \pm 0.62^{\mathrm{c}}$ & $32.00 \pm 2.00^{\mathrm{b}}$ & $40.60 \pm 0.22^{\mathrm{b}}$ & $42.20 \pm 1.08^{c}$ & $41.12 \pm 1.08^{c}$ & $36.32 \pm 2.18^{\mathrm{b}}$ \\
\hline Monocyte (\%) & $3.00 \pm 0.76^{\mathrm{a}}$ & $5.00 \pm 0.42^{\mathrm{b}}$ & $6.00 \pm 0.91^{\mathrm{b}}$ & $5.00 \pm 0.92^{\mathrm{b}}$ & $5.32 \pm 0.10^{\mathrm{b}}$ & $5.30 \pm 0.20^{\mathrm{b}}$ & $5.20 \pm 0.30^{\mathrm{b}}$ \\
\hline Eosinophil (\%) & $3.00 \pm 0.10^{\mathrm{a}}$ & $9.60 \pm 0.66^{b}$ & $9.82 \pm 4.31^{\mathrm{b}}$ & $9.40 \pm 0.52^{b}$ & $8.30 \pm 2.30^{b}$ & $9.00 \pm 2.30^{\mathrm{b}}$ & $6.12 \pm 3.30^{\mathrm{b}}$ \\
\hline Basophil (\%) & $0 \pm 0.20^{\mathrm{a}}$ & $0 \pm 0.22^{\mathrm{a}}$ & $0 \pm 0.25^{\mathrm{a}}$ & $1 \pm 0.03^{\mathrm{a}}$ & $0 \pm 0.24^{\mathrm{a}}$ & $0 \pm 0.23^{\mathrm{a}}$ & $0 \pm 0.23^{\mathrm{a}}$ \\
\hline
\end{tabular}


Khalaf (2013) in hydatidosis infestation of mice. The parasitic infestation in general are responsible for inflammatory activities resulting from the movements, secretions, and toxins of the larvae and bacteria (secondary infection) which can cause anaemic condition and these events especially toxin formation virtually can lead to decrease in haematocrit values (Ipek et al., 2012).

Leucocytes (WBCs), neutrophil and eosinophil counts were significantly $(\mathrm{P}<0.05)$ higher in the parasitic (Hydatidiosis, Myiasis and M. Capillaries) and pathological conditions (Pneumonia, abscess and haemorrhage) of sheep and goats. These results are in agreement with various parasitic and pathological diseases of lungs (Roitt et al., 2002; Yacob et al., 2004). The studies of Al - Nasiri (2006) and Moraitaki et al.(2010) found an increase in the number of leukocytes and eosinophils as our study depicted. However, in contrary to our studies, they reported significant increase of lymphocytes and decrease in the number of neutrophils. The above changes may be considered as a defense mechanism against the inflammatory processes in the body especially in the liver, spleen and kidneys where the inflammation stimulates the bone marrow to produce a large number of WBC (Maclaren and Lacani, 1982). The increase of the eosinophil count could be attributed to the long period of the disease. Nguyen and Diamond (2000) explained eosinophilia in humans is produced due to the ability of parasites to infect the tissue and this agreed with the findings of $\mathrm{Al}$ - Humairy (2010).

\section{Conclusion}

Sheep and goat slaughtered routinely as a source of food in Jammu region were found to have parasitic infestation of Hydatidosis, Myiasis and Mullerius capillaries along with pathological conditions of pneumonia, abscess and haemorrhages. Ante-mortem examination of blood revealed significant decreased of $\mathrm{Hb}, \mathrm{PCV}$ and $\mathrm{RBC}$ in Myiasis infestation of lungs in sheep and goat. MCV decreased significantly in Myiasis of sheep and haemorrhagic lungs of goats. Significant decrease was observed in WBC in sheep and goat having both parasitic and pathological affections of lungs. Significance of present study revolves round the ante-mortem examination of blood before post mortem inspection for public health importance.

\section{REFERENCES}

Al-Humairy, A. KH. (2010). Evaluation of the Activity Datura stramonium Seeds Extracts on Growth and Development of Hydatid Cysts for Echinococcusgranulosus in White Mice Balb/c (Therapeutic , Histologic and Immunologic Study ).Ph. D. Thesis . College of Science, Kufa University (Iraq)

Al-Nasiri , F.S. (2006). Biological and immunological study of hydatid cyst formation in albino mice . Ph.D. Thesis, College of Education, University of Baghdad (Iraq).

Brian R. Walker, Nicki R. Colledge, Stuart H. Ralston, Ian D. Penman (2014). Davidson's principles and practice of medicine (22nd ed.). ISBN 978-0-7020-5035-0

Drake, R.L., Vogl, W., Mitchell, A.W.M. (2014). Gray's anatomy for students (3rd ed.). Edinburgh: Churchill Livingstone/Elsevier. pp. 167-174. ISBN 978-0-70205131-9.

Gracey, J. F. 2009. Meat hygiene. $10^{\text {th }}$ edition pp 153-154. Bailliere Tindall London, UK.

Ipek D.N., Saki C.E. and Cay, M. (2012). The investigation of lipid peroxidation, anti-oxidant levels and some hematological parameters in sheep naturally infested with Wohlfahrtia magnifica larvae. Vet Parasitol., 187 (1-2):112-118.

Khalaf, A.K. (2013). Effect of hydatid cyst infection on some biochemical and haematological parameters in experimental mice Balb $\backslash$ strain. J. college Edu. pure sci., 3 (2) 2013.

Khan, A. and Khan, M.Z. (1996). Neonates calf mortality in Pakistan.III. Immunoglobulin in relation to mortality in buffalo and cow neonates. Buffalo J., 12(2): 243-252.

Lipecka, C., Olech, M., Gruszeek, T.M., Junkuszew, A. and Kuzmak, J. (2010). Haematological and biochemical parameters in blood of lambs born to maedivisnavirus-infected and uninfected ewes. Bulletin of the Veterinary Institute in Pulawy.,54: 135-139.

Lockie, A. (1998). The Family Guide to Homeopathy. pp 123 -124.Penguin, UK. ISBN 0141941235.

Maclaren, D. J. and Lcani, R. N. (1982). Schistosoma mansoni - Acquired resistence of developing Schistosoma to immune attack Invitro. Vet Parositol., 53: 285- 298.

Moraitaki, P., Roussi, P.,Emmanouil, Y., Pechlivanidou, R.., Bitsakou, C., Konstantinou, M. and Marosis, K. (2010). Pulmonary echinococcosis presenting as a pulmonary mass with fever and haemoptysis; a case report. Pneumon. J., 23 (2): 180- 183.

Nguyen, D.T. and Diamond,L.W. (2000) . Diagnostic hematology. 1st ed. Butter Worth Heinemann, Oxford. P.9698.

Pawlina, W.(2015). Histology a Text \& Atlas (7th ed.). pp. 670-678.ISBN 978-1451187427.

Roitt, I., Brostoff, J. and Male, D. (2002). Essential Immunology. Scientific Conference of Animal Wealth Research in the Middle East and North Africa.

Schalm, O.W., Jain, N.C. and Carol, E.J. (1975).Veterinary Haematology, $3^{\text {rd }}$ Edn., Lea and Febiger, Philadelphia, pp.197-199.

Snedecor, George W. and Cochran, William G. (1994), Statistical Methods, Eighth Edition, Iowa State University Press.

Bhandare, S.; Paturkar, A.M.; Waskar, V.S. and Zende, R.J. (2010). Prevelance of micro-organisms of hygienic interest in an organized abattoir in Mumbai, India. $J$ Infect Dev Ctries., 4 (7):454-458

Vegad, J. L. and Swamy, M. 2010. ATextbook of Veterinary Systemic Pathology. pp 28-50. IBDC Publishers, Lucknow.

Yacob, H.T., Jacquiet, Ph., Prevot, F., Bergeaud, J.P., Bleuart, C., Dorchies, Ph. and Hoste, H. (2004). Examination of the migration of first instar larvae of the para- 
Nishchal Dutta et al. / J. Appl. \& Nat. Sci. 9 (3): 1691 -1695 (2017)

site Oestrusovis (Linne 1761) in the upper respiratory tract of artificially infected lambs and daily measurements of the kinetics of blood eosinophilia and mucosal inflammatory response associated with repeated infection. Vet. Parasitol., 126,:339-347
Young B., Lowe, J.S, Stevens, A. and Heath J.W. (2006). Wheater's functional histology : a text and colour atlas. Deakin PJ (illust) (5th ed.). [Edinburgh?]: Churchill Livingstone/Elsevier. pp. 234-250. ISBN 9780443068508 . 